\title{
First record and morphological features of Hemidiaptomus (Occidodiaptomus) ingens (Gurney, 1909) (Copepoda Calanoida) in Italy
}

\author{
Federico MARRONE* and Luigi NASELLI-FLORES \\ Dipartimento di Scienze Botaniche, Università di Palermo, Via Archirafi, 38 - 90123 Palermo, Italy \\ *e-mail corresponding author: kuneli@neomedia.it
}

\begin{abstract}
During a survey, carried out to assess the consistency of microcrustacean fauna inhabiting temporary ponds in Sicily, Hemidiaptomus (Occidodiaptomus) ingens (Gurney, 1909), a large calanoid copepod up to now known only for North-African ponds, Camargue and Corse, was found in the north-western part of the island. Due to its central location in the Mediterranean Sea, Sicily represents a transition zone where several chorological zones of the West Palearctic merge and converge. A brief summary of the existing literature regarding this taxon is given with some morphological considerations on the recently found population which represents the first record for Italy. In particular, the morphological features of the Sicilian population are closely related to those described by Gurney for the specimens collected in the locus typicus (Oued Tindja, Tunisia) and slightly differ from the other European populations.
\end{abstract}

Key-words: Calanoida, Mediterranean region, biogeography, zooplankton, Branchiopoda

\section{INTRODUCTION}

With a surface of about $25700 \mathrm{~km}^{2}$, Sicily, located in the middle of the Mediterranean Sea, is the largest island of the basin. Due to its geographical position, it is a natural "transition zone" for west-palearctic freshwater taxa with different chorological gravitation (Naselli-Flores et al. 1998). Sicilian insularity and climate, characterized by long dry summers and short rainy winters, implies the lack of a well-developed permanent surface hydrographic network. Nevertheless, several hundreds of temporary water bodies are spread throughout the island, and represent the most common and typical freshwater systems in Sicily, as well as in all the Mediterranean region.

In spite of the abundance of temporary water bodies, crustacean fauna of the island has been mainly investigated in man-made lakes (Calvo et al. 1993; NaselliFlores \& Barone 1997; Naselli-Flores et al. 1998) whereas a few scattered samples were randomly collected in these natural environments (Cottarelli \& Mura 1979; Margaritora et al. 1982; Cottarelli \& Mura 1995). In order to fulfil this gap and to get a more detailed inventory of Sicilian crustacean fauna, a series of collections has been carried out in more than 250 temporary water bodies, starting from winter 2000 onwards. This has led to the identification of several crustaceans species new to the island (e.g., Marrone 2003a; Marrone 2003b). Among these, Hemidiaptomus (Occidodiaptomus) ingens (Gurney 1909), a diaptomid calanoid copepod, was found in a temporary pond on Mount Cofano (north-western Sicily). According to our knowledge, this taxon, typical of Tunisian temporary ponds, has never been collected previously in Italy. In this paper, a short description of Sicilian specimens, along with a revision of the available literature and some biogeographical considerations on Hemidiaptomus distribution in the Mediterranean basin are given.

\section{MATERIAL AND METHODS}

The material was collected in a temporary pond (Gorgo di Baglio Cofano: latitude $38^{\circ} 06^{\prime} 11^{\prime \prime} \mathrm{N}$; longitude $\left.12^{\circ} 40^{\prime} 39^{\prime \prime} \mathrm{E}\right)$, located in the north-western part of Sicily. The pond, with a surface area of about $350 \mathrm{~m}^{2}$ and a maximum depth of $40 \mathrm{~cm}$, lies in a clayey depression on a calcareous bedrock, at $249 \mathrm{~m}$ a.s.l. All its watershed is used as a pasture land and the pond itself is used as drinking place for cattle. Its filling generally starts in November and it retains water till late spring, according to temperature trends and precipitation patterns.

Four zooplankton collections were realized in autumn 2003 (1 sampling at the end of November) and winter 2004 (3 samplings: January $14^{\text {th }}$, February $12^{\text {th }}$ and March $\left.15^{\text {th }}\right)$. Samplings were carried out with a 200 $\mu \mathrm{m}$ mesh hand net. Collected samples were fixed in situ with $4 \%$ buffered formalin and sorted in laboratory under an Optika dissecting microscope.

In the sampling dates, the pond showed a rich macrophyte coverage, conductivity values ranging between 400 and $450 \mu \mathrm{S} \mathrm{cm}^{-1}\left(20{ }^{\circ} \mathrm{C}\right)$ and $\mathrm{pH}$ oscillating between 8.2 and 8.5 .

Individuals of Hemidiaptomus (Occidodiaptomus) ingens were set apart, preserved in $80 \%$ ethanol with glycerine and stored in authors' collection. Drawings were realized with an Olympus CX41 microscope equipped with a camera lucida. Copepods were identified according to Dussart (1967, 1969, 1989), Einsle 
Tab. 1. List of the crustaceans occurring in Baglio Cofano pond. ASE: Asiatic-European; CEM: Middle Asiatic-European-Mediterranean; COS: Cosmopolitan; EUM: EuropeanMediterranean; MED: Mediterranean; HOL: Holoarctic; PAL: Palearctic; SCO: Subcosmopolitan; TEM: Turanic-European-Mediterranean; TUE: Turanic-European; WME: West Mediterranean; WPA: West Palearctic. The taxonomic scheme follows Dumont \& Negrea (2002) for branchiopod crustaceans and Dussart \& Defaye (2002) for calanoid copepods.

\begin{tabular}{|c|c|}
\hline Taxa & Chorology \\
\hline \multicolumn{2}{|l|}{ BRANCHIOPODA } \\
\hline \multicolumn{2}{|l|}{ Anomopoda } \\
\hline \multicolumn{2}{|l|}{ Daphniidae } \\
\hline Daphnia (Ctenodaphnia) chevreuxi Richard, 1896 & MED \\
\hline Ceriodaphnia laticaudata P. E. Müller, 1867 & HOL \\
\hline \multicolumn{2}{|l|}{ Moinidae } \\
\hline Moina brachiata (Jurine, 1820) & CEM \\
\hline \multicolumn{2}{|l|}{ Chydoridae } \\
\hline \multicolumn{2}{|l|}{ Aloninae } \\
\hline Alona elegans Kurz, 1875 & EUM \\
\hline \multirow{2}{*}{\multicolumn{2}{|c|}{ 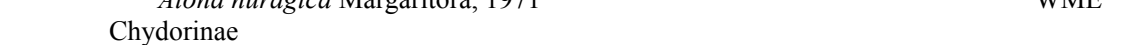 }} \\
\hline & \\
\hline Dunhevedia crassa King, 1853 & $\mathrm{SCO}$ \\
\hline Pleuroxus letourneuxi (Richard, 1888) & MED \\
\hline \multicolumn{2}{|l|}{ Macrothrichidae } \\
\hline Macrothrix hirsuticornis Norman \& Brady, 1867 & $\cos$ \\
\hline \multicolumn{2}{|l|}{ Anostraca } \\
\hline \multicolumn{2}{|l|}{ Chirocephalidae } \\
\hline \multicolumn{2}{|l|}{ Chirocephalinae } \\
\hline Chirocephalus diaphanus Desmarest, 1823 & TEM \\
\hline \multicolumn{2}{|l|}{ Spinicaudata } \\
\hline \multicolumn{2}{|l|}{ Cyzicidae } \\
\hline Cyzicus tetracerus (Krynicki, 1830) & PAL \\
\hline \multicolumn{2}{|l|}{ Notostraca } \\
\hline \multicolumn{2}{|l|}{ Triopidae } \\
\hline Triops cancriformis cancriformis (Lamarck, 1801) & ASE \\
\hline \multirow{2}{*}{\multicolumn{2}{|c|}{ COPEPODA }} \\
\hline & \\
\hline \multicolumn{2}{|l|}{ Diaptomidae } \\
\hline Arctodiaptomus (Arctodiaptomus) stephanidesi (Pesta, 1935) & TUE \\
\hline Diaptomus (Chaetodiaptomus) cyaneus Gurney, 1909 & WPA \\
\hline Hemidiaptomus (Occidodiaptomus) ingens (Gurney, 1909) & WME \\
\hline \multirow{2}{*}{\multicolumn{2}{|c|}{ Cyclopoida }} \\
\hline Cyclopidae & \\
\hline Diacyclops lubbocki (Brady, 1869) & $\cos$ \\
\hline \multirow{2}{*}{\multicolumn{2}{|c|}{ Harpacticoida }} \\
\hline Canthocamptidae & \\
\hline Attheyella crassa (G.O. Sars, 1862) & PAL \\
\hline \multicolumn{2}{|l|}{ OSTRACODA } \\
\hline \multicolumn{2}{|l|}{ Podocopa } \\
\hline \multirow{2}{*}{\multicolumn{2}{|c|}{$\begin{array}{l}\text { Cyprididae } \\
\quad \text { Eucypris virens (Jurine, 1820) }\end{array}$}} \\
\hline & \\
\hline Unidentified juvenes & \\
\hline
\end{tabular}

(1993), Kiefer (1978), Petkvoski (1983) and Stella (1984). Copepods' taxonomic nomenclature follows Dussart \& Defaye (2002). Branchiopod crustaceans were identified according to Alonso (1996), Cottarelli \& Mura (1983) and Margaritora (1985). Chorological categories were applied according to Naselli Flores et al. (1998) and Vigna Taglianti et al. (1992).

\section{RESULTS AND DISCUSSION}

Table 1 shows the composition of the crustacean fauna collected in the pond. Representatives of all the main groups of Branchiopoda co-occur in this environment as well as two different species of Ostracods, and several Copepods. In particular, three calanoid copepods of different size were found in the pond: Arctodiaptomus stephanidesi (Pesta 1935), the smallest, Diaptomus cyaneus Gurney, 1909 and Hemidiaptomus ingens (Gurney, 1909), the largest. According to our knowledge, the latter taxon, although signalled in Southern France (Petit \& Schachter, 1943 in Dussart \& Defaye, 2002) and Corse (Champeau, 1971) has never been reported for Italy.

The genus Hemidiaptomus G.O. Sars, 1903 comprises, according to Dussart \& Defaye (2002), three subgenera: Hemidiaptomus s.str., Gigantodiaptomus Kiefer, 1932 and Occidodiaptomus Borutzky, 1991. It is actually known from Europe, Middle East, Siberia and Northern Africa (Kiefer, 1978) and, although being a 
typically Palearctic genus, was up to now unknown from Sicily. In Italy, it was up to now represented by Hemidiaptomus (Occidodiaptomus) roubaui (Richard, 1888) and Hemidiaptomus (Hemidiaptomus) gurneyi (Roy, 1907). Extended collections recently carried out in Sicily have also revealed the presence of the latter species even in the island, whereas $H(O$.$) roubaui$ seems to be absent (unpublished data).

Hemidiaptomus (Occidodiaptomus) ingens was described by Gurney (1909) as "Diaptomus ingens" on the basis of specimens collected in Oued Tindja (Tunisia). Gauthier (1928) found in Algeria and Tunisia a taxon which, on the basis of the drawings provided by the author himself, lacked the terminal setae on the endopodite of the left P5 and thus were attributed to the subspecies H. (O.) ingens inermis Kiefer, 1955. A third subspecies, Hemidiaptomus ingens provinciae Petit \& Schachter, 1943 was described on the basis of specimens collected in Camargue (Southern France). This subspecies, according to Dussart \& Defaye (2002) has been re-described as $H$. ingens. In addition, on 1969, $H$. ingens was signalled in Corse (Schachter \& Champeau, 1969; Champeau, 1971). Nevertheless, Dussart (1967, 1989), Kiefer (1978), Stella (1984) and Zaouali (1995) had been considering this taxon as exclusive of North Africa. Therefore, on the basis of existing literature, the known distribution of $H$. ingens was limited to Tunisia, Algeria, Camargue and Corse. Actually, Kiefer (1957), by studying two males collected in Oued-Tindja and sent him by Gurney, observed a single seta on the endopodite of the left P5 in both specimens. Anyway, on the basis of further observations that he carried out on these animals, Kiefer (1973) suggested that the presence of one or two long setae at the apex of endopodite of male left P5, the only morphological difference occurring between the two presumptive subspecies, was a plesiomorphic feature, seldom expressed. This way, according to him, $H$. ingens inermis could be a synonym of $H$. ingens ingens, and the presence of these setae an unreliable diagnostic feature for $H$. ingens.

Although nauplii and copepodites were observed in the pond of Baglio Cofano soon after its filling in November, sexually mature specimens (49) were collected for the first time on February $12^{\text {th }} 2004 ; 10$ more were collected on March 2004. In both samples, males were more abundant than females, with a ratio of about 3.5:1. This unexpected sex-ratio would need further investigations. Moreover, it could depend on a sampling bias due to a spatial segregation between sexes, as already observed in other entomostracan species (Cottarelli 1968).

Morphologically, the Sicilian animals are almost identical both with the ones described by Gurney (1909) and with the $H$. ingens ingens described by Kiefer (1957, 1973) on the basis of Oued Tindja specimens (Fig.1, A-K). Anyway, two significant observations, both of them related to the morphology of the endopodite of P5, are worth of being underlined.
Out of 42 examined males, 36 proved to present 1 terminal seta in the endopodite of left P5 (Fig. 1, D, E, G), 6 presented two setae (Fig. 1, F). None of Sicilian males lacks the long setae at the distal end of the endopodite of left P5, this character being typical of the presumptive subspecies inermis (Gauthier 1928, Kiefer 1957). Gurney (1909) shows the endopodite of the male left P5 as bearing two setae in his original drawings of the specimens from Oued Tindja (Tunisia), the locus typicus of the species.

Nevertheless, all the specimens collected in Sicily, as those from Oued Tindja (Tunisia), do present one or two setae while all the Algerian individuals studied by Gauthier (1928) and Kiefer $(1957,1973)$ do not, as well as those collected in Camargue and Corse. Although calanoid copepods very often show a plastic morphology in their chaetotaxy, especially related to the number of setae, with differences detectable even within the same population, these features related to the morphology of the endopodite of the left P5, would need, in our opinion, further investigations.

Collected females also showed a remarkable variability in the number of the spines in the endopodites of $\mathrm{P} 5$, their number ranging from 1 to 3 even in the different legs of the same animal (Fig. 1, A-C). This variability was not noticed by Gurney (1909), Kiefer (1957, 1973, 1978) and Dussart (1967, 1989).

On the basis of the cited literature and our own observations, it seems that the animals from the easternmost part of the distribution range of $H$. ingens show a remarkable variability at level of the ornamentation of the endopodites of both males and females P5, but do always present at least one seta. Conversely, the male specimens of the western populations are always lacking them, thus being "inermis".

The Mediterranean species of Hemidiaptomus show a rather well defined spatial distribution (Fig. 2) with $H$. maroccanus found at the westernmost limit of Mediterranean area, $H$. roubaui in the north-western part of the basin, $H$. gurneyi in the eastern part (up to Israel with the subspecies H. gurneyi canaanita (Dimentman \& Por 1985) and $H$. ingens in the central part.

In the studied pond three calanoid copepod species were present synchronically: Arctodiaptomus (Arctodiaptomus) stephanidesi, Diaptomus (Chaetodiaptomus) cyaneus and Hemidiaptomus (Occidodiaptomus) ingens. A similar calanoid assemblage was described in North Africa and Corse by Gurney (1909), Gauthier (1928) and Champeau (1971), with A. (A.) stephanidesi replaced by other calanoid species of similar size, and in Sardinia by Stella (1984), where H. (O.) ingens is replaced by $H$. (O.) roubaui and $A$. (A.) stephanidesi by Copidodiaptomus numidicus. According to Stella (1984), the synchronical coexistence of different calanoid species in the same pond is possible only when trophic competition is avoided by their different body size, which allow them to exploit food resources of different size. 


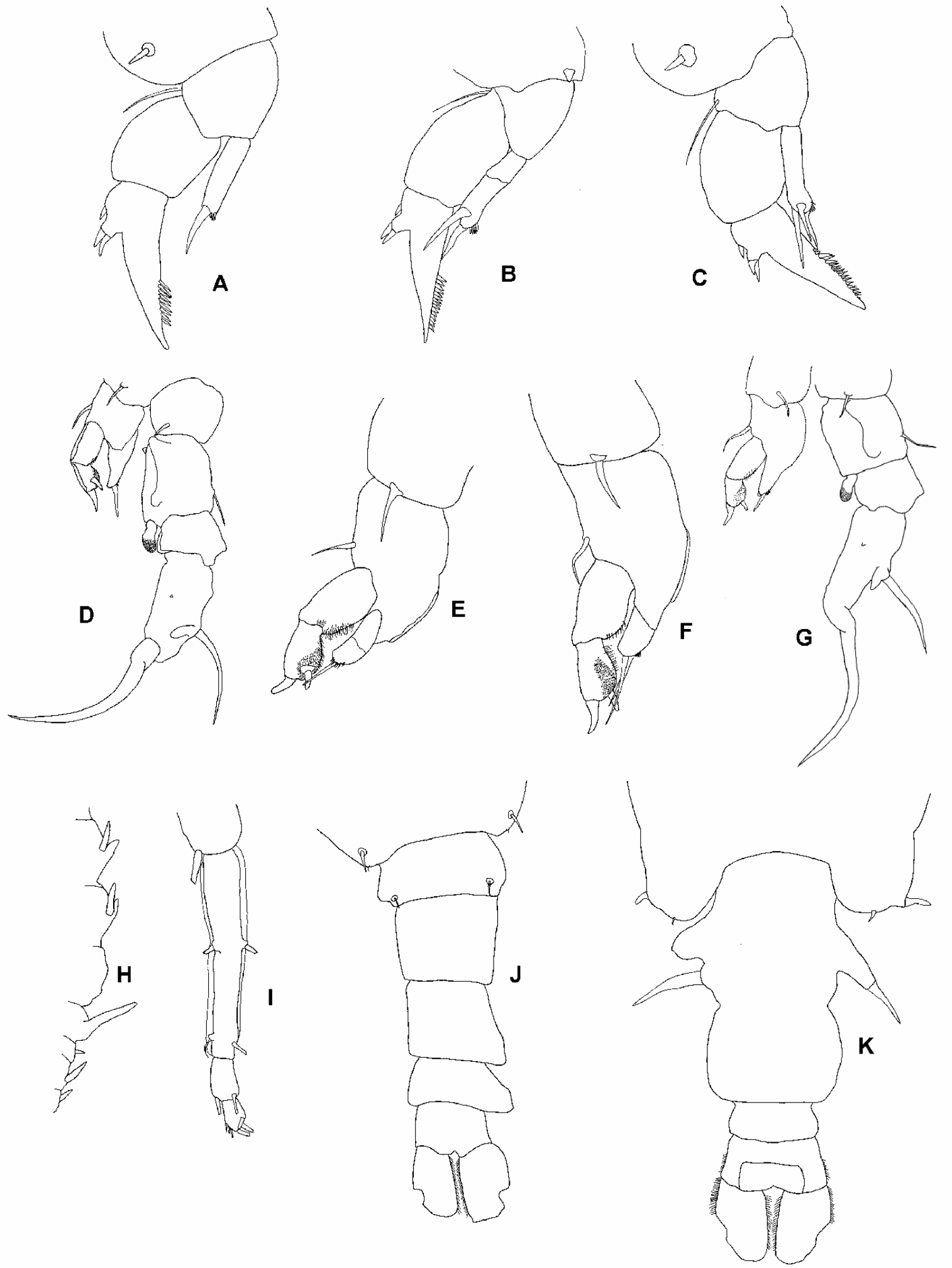

Fig. 1. A, B, C, K: Hemidiaptomus ingens, Female. A, B, C: P5; K: pedigers 4, 5 and urosome, dorsal view. D, E, F, G, H, I, J: H. ingens, Male. D, G: P5; E, F: P5 left; H: right antennula, segments 10-16; I: right antennula, hyaline lamella on antepenultimate segment; J: pediger 5 and urosome, dorsal view. 


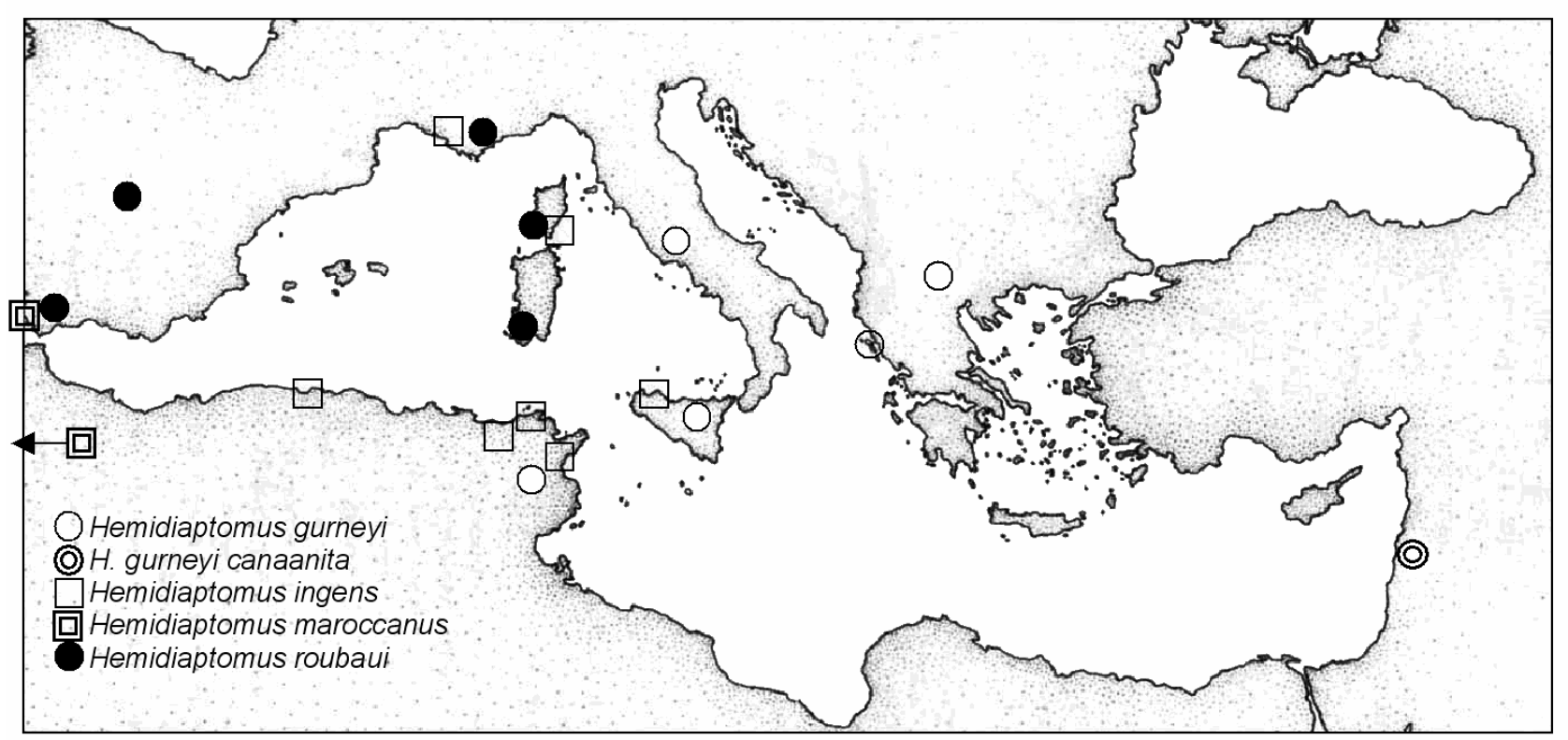

Fig. 2. Known distribution range of Hemidiaptomus spp. in the Mediterranean basin.

Furthermore, a recurrent feature of the ponds inhabited by $H$. ingens is the presence of large branchiopods and cladocerans typical of the "more rainy" Mediterranean regions (Gauthier 1928). Some taxa seem to be strictly related with this diaptomid, co-occurring with it in nearly all the sites: this is the case of Chirocephalus diaphanus, Daphnia (Ctenodaphnia) chevreuxi, Alona spp., Ceriodaphnia spp. The presence of notostracans (Lepidurus apus lubbocki or Triops cancriformis cancriformis) and spinicaudatans belonging to the genus Cyzicus is frequent too. This crustacean assemblage is rather typical in low altitude Mediterranean temporary ponds retaining water for a period of time long enough to allow the development of a discrete macrophyte canopy and to sustain the relatively long lifespan of these taxa.

\section{ACKNOWLEDGMENTS}

The authors wish to thank Fabio Stoch for the valuable help he gave with bibliographical sources and identification of cyclopoid and harpacticoid copepods and Valentina Pieri for the identification of the ostracods. An anonymous referee is acknowledged for helpful suggestions on the manuscript.

\section{REFERENCES}

Alonso, M. 1996. Crustacea, Branchiopoda. Fauna Iberica. 7. Museo Nacional de Ciencias Naturales. CSIC. Madrid: $486 \mathrm{pp}$.

Calvo, S., R. Barone, L. Naselli Flores, C. Fradà Orestano, G. Dongarrà, A. Lugaro \& G. Genchi. 1993. Limnological studies on lakes and reservoirs of Sicily. Naturalista siciliano, XVII (Suppl.): 292 pp.

Champeau, A. 1971. Originalité du peuplement de Copépodes dans les eaux temporaires de Basse-Provence et de Corse. Annales de l'Université de Provence, Science, 45: 55-80.
Cottarelli, V. 1968. Su Branchipus alpinus Colosi (Euphyllopoda, Anostraca). Archivio zoologico italiano, 53: 353-365.

Cottarelli, V. \& G. Mura. 1979 Reperti inediti di crostacei anostraci, notostraci e concostraci di Calabria e Sicilia. Bollettino del Museo Civico di Storia Naturale di Verona, 6: 353-361.

Cottarelli, V. \& G. Mura. 1983. Anostraci, Notostraci, Concostraci. Guide per il riconoscimento delle specie animali delle acque interne italiane. Consiglio Nazionale delle Ricerche, $18: 73 \mathrm{pp}$.

Cottarelli, V. \& G. Mura. 1995. Ricerche zoologiche della nave oceanografica "Minerva" (C.N.R.) sulle isole circumsarde. XXV. Ulteriori reperti di anostraci, notostraci e spinicaudati (crostacei branchiopodi) della fauna italiana. Annali del Museo Civico di Storia Naturale "G. Doria", Genova, 90: 599-607.

Dumont, H.J. \& S.V. Negrea. 2002. Introduction to the class Branchiopoda. Guides to the Identification of the Microinvertebrates of the Continental Waters of the World. SPB Academic Publishing, The Hague: 398 pp.

Dussart, B. 1967. Les Copépodes des eaux continentales d'Europe occidentale. I. Calanoides et Harpacticoides. Ed. Boubée \& Cie, Paris: 500 pp.

Dussart, B. 1969. Les Copépodes des eaux continentales d'Europe occidentale. II Cyclopoïdes et Biologie. Ed. Boubée \& Cie, Paris, 292 pp.

Dussart, B. 1989. Crustacés Copépodes Calanoides des eaux interieures africaines. Crustaceana, Supplement 15. $206 \mathrm{pp}$.

Dussart, B. \& D. Defaye. 2002. World directory of Crustacea Copepoda of inland waters. I. Calaniformes. Backhuys Publishers, Leiden: 276 pp.

Einsle, U. 1993. Crustacea Copepoda. Calanoida und Cyclopoida. Susswasserfauna Mitteleuropas, 8/4-1, Gustav Fisher Verlag.

Gauthier, H. 1928. Recherches sur la faune des eaux continentales de l'Algérie et de la Tunisie. Imp. Minerva, Alger: $416 \mathrm{pp}$.

Gurney, R., 1909. On the Fresh-water Crustacea of Algeria and Tunisia. Journal of the Royal Microscopical Society, 443: 273-305.

Kiefer, F. 1957. Zur Kenntnis von Hemidiaptomus (Gigantodiaptomus) robaui (Richard, 1888) und $H$. (G.) ingens 
(Gurney, 1909) (Crust. Cop.). Zoologischer Anzeiger, 159: 311-321.

Kiefer, F. 1973. Zur Kenntnis der roubaui-Gruppe der Gattung Hemidiaptomus G.O. Sars (Copepoda). Crustaceana, 25: 281-291.

Kiefer, F. 1978. Das Zooplankton der Binnengewaesser. Freilebende Copepoda. Die Binnengewaesser, Band 26 Teil 2: 1-343. E.Schweizerbart'sche Verlagbuchhandlung, Stuttgart.

Margaritora, F.G. 1985. Cladocera. XXIII, Fauna d'Italia. Ed. Calderini, Bologna: 389 pp.

Margaritora, F.G., L. Mastrantuono, D. Crosetti \& F. Lombardi. 1982. Contributo alla conoscenza della fauna ad entomostraci delle acque interne della Sicilia. Animalia, 9 $(1 / 3): 87-102$.

Marrone, F. 2003a. Branchiopod Crustaceans from circumSicilian islands, I: Ustica (southern Thyrrenian Sea, Italy) (Crustacea, Branchiopoda). Il Naturalista Siciliano, 27: 255-262.

Marrone, F. 2003b. On some cladocerans new to Sicily (southern Italy) (Crustacea Branchiopoda). Il Naturalista Siciliano, 27: 263-270.

Naselli-Flores, L. \& R. Barone. 1997. Importance of water level fluctuation on population dynamics of cladocerans in

Received: May 2003

Accepted: September 2003 a hypertrophic reservoir (Lake Arancio, south-west Sicily, Italy). Hydrobiologia, 360: 223-232.

Naselli-Flores, L., R. Barone \& M. Zunino. 1998. Distribution patterns of freshwater zooplankton in Sicily (Italy). Verh. int. Ver. Limnol., 26: 1973-1980.

Petkovski, T.K. 1983. Calanoides - Calanoida (Crustacea Copepoda). Faune de Macedonie. 5. Musée Histoire Naturelle de Macedonie, Skopje: $182 \mathrm{pp}$.

Schachter, D. \& A. Champeau. 1969. Contribution a l'étude écologique de la Corse. I. Les Copépodes des eaux stagnantes. Vie Milieu, 20: 41-56.

Stella, E. 1984. Copepoda: Calanoida. XXI Fauna d'Italia. Ed. Calderini, Bologna: $101 \mathrm{pp}$.

Vigna-Taglianti, A., P.A. Audisio, C. Belfiore, M. Biondi, M.A. Bologna, G.M. Carpaneto, A. De-Biase, S. DeFelici, E. Piattella, T. Racheli, M. Zapparoli \& S. Zoia. 1992. Riflessioni di gruppo sui corotipi fondamentali della fauna W-paleartica ed in particolare italiana. Biogeographia, 16: 159-178.

Zaouali, J. 1995. Limnology in Tunisia. In: B. Gopal \& R.G. Wetzel (Eds), Limnology in Developing Countries. Societas Internationalis Limnologiae: 41-61. 